\title{
Commentary
}

CrossMark

\& clickfor upd

\section{Could Angiotensin Converting Enzyme 2 Inhibitor (ACE2) be the First Line of Defence against SARS-CoV-2, Diseases Covid-19?}

\section{Daniel Kerr Baines}

\author{
The Lancaster University, Lancaster, United Kingdom
}

\begin{abstract}
Received | April 05, 2020; Accepted | April 25, 2020; Published | April 29, 2020
*Correspondence | Daniel Kerr Baines, The Lancaster University, United Kingdom; Email: d.k.baines@lancaster.ac.uk

DOI | http://dx.doi.org/10.17582/journal.hv/2020/7.2.20.22

Citation | Baines, D.K. 2020. Could Angiotensin converting enzyme 2 inhibitor (ACE2) be the first line of defence against SARS-CoV-2, diseases Covid-19. Hosts and Viruses, 7(2): 20-22.
\end{abstract}

Keywords: ACE2, Covid-19, SARS-CoV-2, Pandemic, Disease, First line defence

$\mathrm{B}$ y now the majority of the world knows about the CoVID-19 disease caused by the Coronavirus strain, SARS-CoV-2. Starting in Wuhan, China the disease has spread globally, like wildfire, becoming a pandemic. The disease has closed boarders, placed people on lock down and has already played a crucial role in the ever downward spiralling global stock markets. CoVID-19 has currently taken the lives of over 100,000 people and overwhelmed the health services of major countries including Italy and Spain. Although, in some countries it has reached its peak and is beginning to level. Leading scientists must search for a vaccine faster than in any other pandemic in human history.

Every day more is being learned about the disease allowing for the possible vaccine development. What is known about the mechanism of action of the virus is the viral $\mathrm{S}$ protein binds to angiotensin converting enzyme 2 (ACE2) receptor (Walls et al., 2020). This allows the release of the viral RNA through the mechanism of the fusion through fusion of the viral envelope to the cell membrane, by the $\mathrm{S}$ protein on the virus (Hoffmann et al., 2020). It has also been said that priming of the $\mathrm{S}$ spike by proteases from the host cell by serine protease TMPRSS2 is a vital component utilised for viral entry. S1/S2 and S2' cleavages occur on the $\mathrm{S}$ protein of the virus. This would lead ACE2 inhibitors and serine protease inhibitors as April 2020 | Volume 7 | Issue 2 | Page 20 possibly the leading source to stopping the virus. In simple terms, inhibit the viral entry to the cell and you inhibit any further viral production.

ACE2 can be found as a single pass cell surface receptor on most tissues of most organ systems. These include the arteries, heart, lungs, liver, kidneys the intestines, lymph nodes, spleen, thymus and bone marrow (Hamming et al., 2004) to name a few. In fact through a PCR investigation (Harmer et al., 2002) found homologous ACE2 in 72 different human tissues. In normal function ACE2 is vital for the protection of peripheral tissues and has been noted as having many potential therapeutic viabilities, with various diseases (Xia and Lazartigues, 2010). The molecule has also been shown to be vital in the protection of baroreflex and autonomic function as well as the reduction of oxidative stress.

Initially, up on the first set of data, patients who use Angiotensin converting inhibitors were urged to stop using such medications. This was a blanked direction across all angiotensin based drugs (Marin, 2020). This mass stopping of medication could have further future implications, but it was necessary given the information at the time, coupled with the current situation. There have been multiple studies which suggest angiotensin converting enzyme (ACE) has a role in the regulation in the role of $\mathrm{ACE} 2$. One such study by 
(Koka et al., 2008) suggested that angiotensin II (the product of the angiotensin converting enzyme) downregulates ACE2. They also stated that the mediation occurred via the AT1-ERK/p38 MAPK pathways. Other studies have shown that patients with diabetes mellitus, who are taking ACE inhibitors show an increase in $\mathrm{ACE} 2$, leaving those with diabetes mellitus in the highest risk category.

Although, sharing the same homology (Tikellis and Thomas, 2012) and both components of the renin-angiotensin system (RAS), ACE and ACE2 are 2 different molecules. Once cleaved into angiotensin by renin, angiotensin 1 is converted into angiotensin 2 by ACE (Brosnihan et al., 2005). However, the main role of ACE2 is the conversion of angiotensin II into angiotensin $1-9$ (Tikellis and Thomas, 2012), with ADAM17 being a known cleaver of ACE2 (Chamsi-Pasha et al., 2014). ACE2 is not inhibited by angiotensin converting enzyme inhibitors (Zisman, 2005). It was in part the regulation of ACE1 has on ACE2 and ACE2 being a site of entry for the virus that lead to the advice to stop taking angiotensin converting enzyme. In a sense inhibiting angiotensin converting enzyme could allow for more ACE2 (study depending) allowing for a further increase of viral cellular entry points (Ferner, 2020) and as such increasing the viral load.

As mentioned ACE2 holds a critical role in a number a vital cellular and molecular functions. Long term inhibition can cause more problems than medication itself can be worth but as a short term measure ACE2 inhibitors have to be looked into as a method of reducing a patient's viral load. There have been promising advances in this area: (Lei Fanf, 2020) successfully inhibited the adherence of the SARS-CoV-2 S spike through the modification of glycosylation. Essentially no glucose molecule could be transferred form the $\mathrm{S}$ spike molecules to the ACE2 receptor and thus no binding, in vitro. The inhibition of the glycosylation was achieved using Chloroquine (Vincent et al., 2005), hydroxychloroquine. Both molecules have been shown on multiple studies to significantly reduce the viral load in the infected person. When tested against SARS-CoV-2 infected in vitro cells (Hoffmann et al., 2020). Both are relatively cheap drugs used globally to treat malaria and have been already labelled in other countries as a cost effective method of treating SARS-CoV-2 (Gautret et al., 2020). In small cohort study by (Gautret et al., 2020) all 20 patients who were Covod-19 positive and treated with hydroxychloroquine viral load considerably decreased or disappeared. Another investigation by (Liu et al., 2020) started hydroxychloroquine is effective at inhibiting the SAR-CoV-2 virus.

The serine protease TMPRSS2 has been found to be crucial for the priming of the $\mathrm{S}$ spike by (Hoffmann et al., 2020) the host cell. The investigation blocked the entry of the virus by inhibiting TMPRSS2 through the use of a TMPRSS2 inhibitor camostat mesylate, when tested in vivo using Caco-2 cells and vero-TMPRSS2 cells (Hoffmann et al., 2020).

So, in summary the SARS-CoV-2 virus achieves cellular entry through binding to ACE2 receptors. Any inhibition of ACE2 or the priming of the $\mathrm{S}$ spike defends against entrance to the cell by the virus. A known, available, mass produced anti-malarial drug, namely hydroxychloroquine inhibits ACE2 receptors and reduces the viral load in infected patients. The same effect is seen using a TMPRSS2 inhibitor, camostat mesylate. Why are these not our first line of defence? Some would argue that there are negative side effects associated with the drugs, but their potential benefits are likely to outweigh the risk. The use of these drugs in the fight against life-threatening diseases such as malaria, and now CoVID-19, could prove imperative in maintaining the safety of our population.

\section{References}

Brosnihan, K. B., Neves, L. A. \& Chappell, M. C. 2005. Does the angiotensin-converting enzyme (ACE)/ACE2 balance contribute to the fate of angiotensin peptides in programmed hypertension? Hypertension, 46, 1097-9.

Chamsi-Pasha, M. A., Shao, Z. \& Tang, W. H. 2014. Angiotensin-converting enzyme 2 as a therapeutic target for heart failure. Curr Heart Fail Rep, 11, 58-63.

Ferner, J. K. A. A. R. E. 2020. Angiotensin converting enzyme (ACE) inhibitors and angiotensin receptor blockers in COVID-19. vcentre fro evidence-based medicine, Nuffeld Department of Primary Care Health Science.

Gautret, P., Lagier, J. C., Parola, P., Hoang, V. T., Meddeb, L., Mailhe, M., Doudier, B., Courjon, J., Giordanengo, V., Vieira, V. E., Dupont, H. T., Honore, S., Colson, P., Chabriere, E., La 
Scola, B., Rolain, J. M., Brouqui, P. \& Raoult, D. 2020. Hydroxychloroquine and azithromycin as a treatment of COVID-19: results of an open-label non-randomized clinical trial. Int $J$ Antimicrob Agents, 105949.

Hamming, I., Timens, W., Bulthuis, M. L., Lely, A. T., Navis, G. \& Van Goor, H. 2004. Tissue distribution of ACE2 protein, the functional receptor for SARS coronavirus. A first step in understanding SARS pathogenesis. J Pathol, 203, 631-7.

Harmer, D., Gilbert, M., Borman, R. \& Clark, K. L. 2002. Quantitative mRNA expression profiling of ACE 2, a novel homologue of angiotensin converting enzyme. FEBS Lett, 532, 107-10.

Hoffmann, M., Kleine-Weber, H., Schroeder, S., Kruger, N., Herrler, T., Erichsen, S., Schiergens, T. S., Herrler, G., Wu, N. H., Nitsche, A., Muller, M. A., Drosten, C. \& Pohlmann, S. 2020. SARS-CoV-2 Cell Entry Depends on ACE2 and TMPRSS2 and Is Blocked by a Clinically Proven Protease Inhibitor. Cell.

Koka, V., Huang, X. R., Chung, A. C., Wang, W., Truong, L. D. \& Lan, H. Y. 2008. Angiotensin II up-regulates angiotensin I-converting enzyme (ACE), but down-regulates $\mathrm{ACE} 2$ via the AT1-ERK/p38 MAP kinase pathway. Am J Pathol, 172, 1174-83.

Lei Fanf, G. K. A. M. B. 2020. Antihypertensive drugs and risk of COVID-19? The Lancet.

Liu, J., Cao, R., Xu, M., Wang, X., Zhang, H., Hu, H., Li, Y., Hu, Z., Zhong, W. \& Wang, M. 2020. Hydroxychloroquine, a less toxic derivative of chloroquine, is effective in inhibiting SARSCoV-2 infection in vitro. Cell Discov, 6, 16.

Marin, G. H. 2020. Facts and reflections on COVID-19 and anti-hypertensives drugs. Drug Discov Ther.

Tikellis, C. \& Thomas, M. C. 2012. Angiotensin-Converting Enzyme 2 (ACE2) Is a Key Modulator of the Renin Angiotensin System in Health and Disease. Int J Pept, 2012, 256294.

Vincent, M. J., Bergeron, E., Benjannet, S., Erickson, B. R., Rollin, P. E., Ksiazek, T. G., Seidah, N. G. \& Nichol, S. T. 2005. Chloroquine is a potent inhibitor of SARS coronavirus infection and spread. Virol J, 2, 69.

Walls, A. C., Park, Y. J., Tortorici, M. A., Wall, A., Mcguire, A. T. \& Veesler, D. 2020. Structure, Function, and Antigenicity of the SARSCoV-2 Spike Glycoprotein. Cell.

Xia, H. \& Lazartigues, E. 2010. Angiotensin-converting enzyme 2: central regulator for cardiovascular function. Curr Hypertens Rep, 12, 1705.

Zisman, L. S. 2005. ACE and ACE2: a tale of two enzymes. Eur Heart J, 26, 322-4. 